\title{
Review of Selected Bio-Wastes as Potential Materials for Alkali-Activation for Cement-Based Products
}

\author{
K. A. Olonade ${ }^{1 *}$, H. Mohammed ${ }^{2}$ \\ ${ }^{1}$ Department of Civil and Environmental Engineering, University of Lagos, Lagos, Nigeria. \\ ${ }^{2}$ Department of Civil Engineering, Obafemi Awolowo University, Ile-Ife, Nigeria.
}

\begin{abstract}
There is growing need to finding alternative binder for Ordinary Portland Cement (OPC) as a result of the environmental hazards associated with its production. This paper presents the result of the review of selected bio-wastes as potential materials for alkali-activation in cement-based products. Studies carried out by several authors on the use of ashes from rice husk, cassava peel, sugarcane straw, corn cob and coconut shells were critically reviewed, while their chemical compositions as well as other criteria for alkali activation were identified. The review showed that the combined composition of $\mathrm{SiO}_{2}, \mathrm{Al}_{2} \mathrm{O}_{3}$ and $\mathrm{Fe}_{2} \mathrm{O}_{3}$ were in the ranges of $67.90-93.60,46.59-72.25$, $73.79-83.02,41.13-78.30$ and $71.3-77.57 \%$ for rice husk ash, cassava peel ash, sugarcane straw ash, corn cob ash and coconut shell ash, respectively. These values met the requirement of ASTM 618 for materials to be considered as pozzolan, while the hydraulic coefficients of the ashes were also found comparable to notable industrial wastes that have been utilized for alkali-activation. It was also found that these materials are still not explored for alkali-activation. The paper concluded that the ash from these materials could be alkali activated to produce binders in cement-based products due to their potential properties.
\end{abstract}

KEYWORDS: Bio-wastes, alkali-activation, geopolymer, hydraulic activity coefficient, pozzolan.

[Received August 16, 2018; Revised December 12, 2018; Accepted March 15, 2019]

Print ISSN: 0189-9546 | Online ISSN: 2437-2110

\section{INTRODUCTION}

There is growing interest in finding alternative binder to Ordinary Portland Cement (OPC) in cement-based products for many reasons: the alarming emission of greenhouse gases during OPC production, cement industry alone contributes large amount of $\mathrm{CO}_{2}$ to the atmosphere next to automobile (Boden et al. 2016), and it is responsible for between 6 and $10 \%$ of the total $\mathrm{CO}_{2}$ emitted yearly (Metz, 2007). The cement industry has also been implicated in the degradation of eco-system, several forms of pollution and huge energy consumption, as well as massive earth depletion (UNDESA, 2015).

Considering the uses to which cement is put, it is expected that the demand for cement will continue to rise since cement is central to infrastructure development of any nation; hence, tendency for its production will be motivated. As at 2015, the global demand for cement was put at $4.6 \mathrm{Gt} / \mathrm{a}$ (Carstensen and Rapf, 2008) and this is expected increase to as high as $13.5 \mathrm{Gt} / \mathrm{a}$ by 2050 (CEMBUREAU, 2016; Edwards, 2016). The simple implication of this is, if no alternative is found, a world that will be a threat to its habitant could be created.

Concerted efforts are being made from different sectors to reduce the amount of $\mathrm{CO}_{2}$ emitted by the cement industries. Fuel used in powering cement machines is improved, energy efficiency techniques are developed, and carbon capture and utilization are equally promoted as well as material substitute for cement. The details of these approaches are summarized in the recently published report

*Corresponding author: olonade1431ah@gmail.com of United Nations Environment Program Sustainable Building and Climate Initiative (UNEP-SBCI) (Scrivener et al., 2016).

Alkaline activation of materials rich in silica and alumina is becoming attractive and many materials have been explored. This technique has potential to complement the global demand for binder in infrastructure development (Glasby et al. 2015). The added advantage of the alkaliactivated binder over Portland cement is its local adaptation, once suitable materials are available. The alkali-activated binder gains strength rapidly, offering great advantages in precast operations with low heat of hydration, while hardened binder is watertight and less soluble than Portland cement hydrate. Furthermore, the cost could be lower where precursor material is a waste product. In this review, an attempt is made to present the chemistry of alkali activation and provide a detailed account of the materials that have been utilized with their performance indices. The review also assesses selected potential agricultural wastes for alkaliactivation that have not been explored.

\section{BIO-WASTES: AVAILABILITY AND POZZOLANIC POTENTIAL}

Agricultural wastes generation is on the increase with increase in agricultural practices worldwide, especially in many African Countries. Unfortunately, effective disposal of these wastes has been a major challenge. Most often than not, the wastes are left to biodegrade, producing offensive odour, 
Table 1: The chemical composition of selected ashes of bio-based materials.

\begin{tabular}{|c|c|c|c|c|c|}
\hline $\begin{array}{l}\text { Oxides/ } \\
\text { LOI }\end{array}$ & $\begin{array}{c}\text { RHA (\%) } \\
\text { (El-Sayed } \text { et al. } \\
\text { 2006; } \\
\text { Ramezanianpour } \text { et } \\
\text { al., 2009; Bui } \text { et al. } \\
\text { 2005; Zhang and } \\
\text { Mohan, 1996; } \\
\text { Tashima } \text { et al., } \\
\text { 2012) }\end{array}$ & $\begin{array}{c}\text { CPA (\%) } \\
\text { (Salau } \text { et al., } \\
\text { 2013; Salau and } \\
\text { Olonade, 2011; } \\
\text { Olonade et al., } \\
\text { 2014; Aderemi. } \\
\text { 2017; Olutaiwo } \\
\text { and Adanikin, } \\
\text { 2016) }\end{array}$ & $\begin{array}{c}\text { SCSA }(\%) \\
\text { (Reddy and } \\
\text { Prasad, 2017; } \\
\text { Cordeiro et al., } \\
\text { 2017; Santos et } \\
\text { al., 2015; Moise's } \\
\text { Frı'as et al., } \\
\text { 2007; Calligaris } \\
\text { et al., 2015) }\end{array}$ & $\begin{array}{c}\text { CCA }(\%) \\
\text { (Kamau et al., } \\
\text { 2016; Olonade et } \\
\text { al., 2017; Bala et } \\
\text { al., 2016; Raheem } \\
\text { et al., 2011; } \\
\text { Nimityongskul and } \\
\text { Daladar. 1995) }\end{array}$ & $\begin{array}{c}\text { CSA (\%) } \\
\text { (Arum et al., 2013; } \\
\text { Nagarajan et al., } \\
\text { 2014; Tinga et al., } \\
\text { 2016; Utsev and } \\
\text { Taku, 2012, Bello, } \\
\text { 2017) }\end{array}$ \\
\hline $\mathrm{SiO}_{2}$ & $65.90-92.9$ & $33.2-58.0$ & $62.43-73.4$ & $37.26-66.38$ & $37.97-58.86$ \\
\hline $\mathrm{Al}_{2} \mathrm{O}_{3}$ & $0.04-1.78$ & $7.21-12.80$ & $0.70-12.53$ & $1.09-7.90$ & $9.24-24.12$ \\
\hline $\mathrm{Fe}_{2} \mathrm{O}_{3}$ & $0.16-0.43$ & $1.41-7.74$ & $0.4-10.35$ & $2.78-7.40$ & $3.20-15.48$ \\
\hline $\mathrm{CaO}$ & $0.55-2.40$ & $6.94-10.47$ & $3.98-12.20$ & $1.80-11.57$ & $0.57-6.6$ \\
\hline $\mathrm{MgO}$ & $0.35-3.11$ & $1.33-5.02$ & $0.96-2.79$ & $2.06-3.15$ & $1.03-16.2$ \\
\hline $\mathrm{SO}_{3}$ & $0.10-0.69$ & $0.72-4.05$ & $0.11-4.10$ & $0.59-1.44$ & $0.46-0.71$ \\
\hline $\mathrm{Na}_{2} \mathrm{O}$ & $0.02-2.46$ & $0.03-1.39$ & $0.05-0.50$ & $0.04-0.90$ & $0.45-4.11$ \\
\hline $\mathrm{K}_{2} \mathrm{O}$ & $0.72-3.68$ & $4.64-20.58$ & $3.05-6.98$ & $4.92-37.09$ & $0.52-3.58$ \\
\hline LOI & $5.14-9.71$ & $4.18-16.39$ & $1.03-61.60$ & $6.49-16.18$ & $9.73-11.94$ \\
\hline $\begin{array}{l}\mathrm{SiO}_{2}+\mathrm{Al}_{2} \mathrm{O}_{3}+ \\
\mathrm{Fe}_{2} \mathrm{O}_{3}\end{array}$ & $67.90-93.60$ & $46.59-72.23$ & $73.79-83.02$ & $41.13-78.30$ & $71.30-77.57$ \\
\hline Activation $\left({ }^{\circ} \mathrm{C}\right)$ & $600-750$ & $650-700$ & $650-800$ & $600-750$ & $600-750$ \\
\hline
\end{tabular}

while sometimes, they are burnt for no benefit in returns. In the recent past, efforts were being geared towards finding effective use of these materials for construction purposes as partial replacement of cement in concrete. However, there is still doubt as to the abundance and suitability of these potential raw materials for construction purposes. This section $\mathrm{x}$-rays the potential of ash from common agricultural wastes that could serve as precursors for alkali activation. It is expected that they could serve as the basis for developing zero-cement concrete for bridging infrastructure deficit that pervaded the continent.

\section{A. Rice husk ash (RHA)}

Rice is a food crop that can be found in almost all the continents of the world and it is grown largely to meet its global demand. Statistics have shown that about 600 million metric tonnes $(\mathrm{mmt})$ of rice paddy was produced in 2003 while it rose to about $640 \mathrm{mmt}$ in 2007 globally (Bronzeoak, 2003 and Calpe, 2007). As at 2016, the global rice production reached $748 \mathrm{mmt}$ with a promising increase in rice production in Africa due to growing conducive environment, which will increase production by 5\% (FAO, 2016). It has been estimated that about $20 \%$ of the weight of rice paddy is husk, indicating that nearly $150 \mathrm{mmt}$ of rice husks are produced only in 2016. Rice husk as bio-waste is often disposed of by burning, leading to environmental challenges.

Not until 1924 when the use of rice husk ash (RHA) in concrete was patented, the RHA was considered completely a waste (Pitt, 1972). Since then RHA, as pozzolan in concrete, has been a prominent discourse among the researchers with different propositions. It is found that RHA contains amorphous silica, like what is found in most natural pozzolanic materials. RHA is produced by either open burning or controlled burning. Typical composition of RHA is presented in Table 1. The values in the table were obtained from studies carried out by the cited authors as presented in the table. It is shown that RHA was produced within the temperature range of $600-750^{\circ} \mathrm{C}$. Its chemical composition varies which may be due to the varieties of rice and the treatment techniques, however the values obtained still meet the provisions of ASTM C 618, (2008), as the combined silica, alumina and ferric was more than $70 \%$. Though, chemical composition may not be a decisive condition to reject or accept a material as pozzolan but could be used as preliminary selection, while performance in concrete is of essence (Taylor 1997). Meanwhile, RHA concrete has shown superior performance over normal concrete. Presence of RHA as partial substitute of cement is found to enhanced workability, improved strength, increase durability and reduce shrinkage among other enhanced properties (Tashima et al., 2012 and Ramezanianpour et al., 2009).

\section{B. Cassava Peel Ash (CPA)}

Cassava is used for both domestic and industrial purposes, resulting in heaps of peels worldwide. FAO (2016) reported that more than $54 \%$ of world's cassava is produced in Africa with Nigeria as the highest producer of cassava with an annual production of $54 \mathrm{mmt}$ (Adesina, 2012), representing about $20 \%$ of global cassava production. Meanwhile, cassava is the fastest growing food crop in Africa such that its cultivation is extending to the dry region of the continent (Figure 1). Adesanya et al. (2008) reported that between 20 and $30 \%$ of cassava tuber is cassava peel. As of 2014, the estimated cassava peels generated in Nigeria was $14 \mathrm{mmt}$ (Olonade, 2017). Cassava peels are usually used for animal feeds but its low protein content and high quantity of hydrocyanide limit its full utilization for animal feeds.

Cassava peels burnt at controlled or uncontrolled temperature showed that its ash possessed an appreciable quantity of silica and alumina for use as pozzolan in concrete (Table 1). Mechanical and some durability properties of concrete containing about $15 \%$ of CPA as a replacement for cement have been studied with promising results (Salau et al., 2013; Salau and Olonade, 2011). 


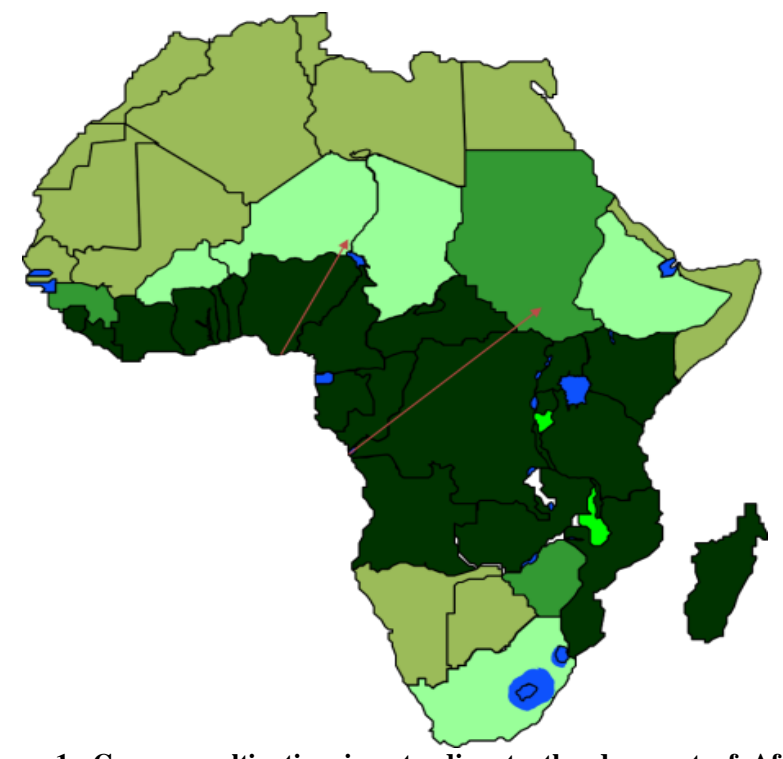

Figure 1: Cassava cultivation is extending to the dry part of Africa (Mahungu and Anga, 2007).

\section{Sugarcane straw ash (SCSA)}

Sugar cane, tall perennial grass, and fibrous stalk is a primary source of sugar, ethanol, and jaggery. During harvesting and processing, a large quantity of straw is generated as waste, a limited quantity of which is used as fodder in livestock feed. But a substantial part of the straw is disposed by burning. Today, sugar cane straw ash (SCSA) is another bio-based material that has received attraction of many researchers for use as pozzolanic materials. In Table 1, it is found that chemical composition of SCSA indicated that it is a potential pozzolan as it met the provision of ASTM C 618. Performance of concrete containing a fraction of SCSA as a substitute for cement has been extensively investigated (Cordeiro et al., 2017; Santos et al., 2015; Moisés Fr1'as et al., 2007; Calligaris et al., 2015). Recycling SCSA in this form will be able to rescue the environment with the pollution caused by the huge amount of sugar cane straw produced annually. As of 2015, about $175 \mathrm{mmt}$ of sugarcane was produced globally (Taylor, 2016). Of the sugarcane stalk, about $22 \%$ is straw, when $3-5 \%$ is ash (Reddy and Prasad, 2017).

\section{Corncob ash (CCA)}

Corncob is the central stalk that holds corns together. Corn is an essential cereal crop produced in large quantities worldwide. Global annual production of corn has reached $1,037 \mathrm{mmt}$ with sustainable supply (Figure 2). Once corns are shelled, the cobs left represent between 16 to $20 \%$ of the weight of unshelled corn. Going by this record, a minimum of $166 \mathrm{mmt}$ of corn cobs are generated globally. In industrialized corn processing plants, corncobs can be used as fuel, while in the less developed setting they are left to either rot away or burnt for no benefit in return. Nevertheless, when corn cobs are burnt to ash, they could be useful as pozzolanic material. Several studies have been carried out on the chemical composition CCA and its use as partial replacement of cement in concrete production. The chemical composition of CCA obtained by some researchers suggested that CCA is a promising pozzolanic material that can be incorporated in producing cement-based products (Table 1). The chemical composition of CCA also met the criteria of the ASTM C-618 with combined silica, alumina and ferric greater than $70 \%$. Experimental studies have equally been conducted to evaluate mechanical and durability performance of CCA concrete with positive results (Arum et al., 2013; Nagarajan et al., 2014; Tinga et al., 2016; Utsev and Taku, 2012, Bello, 2017).

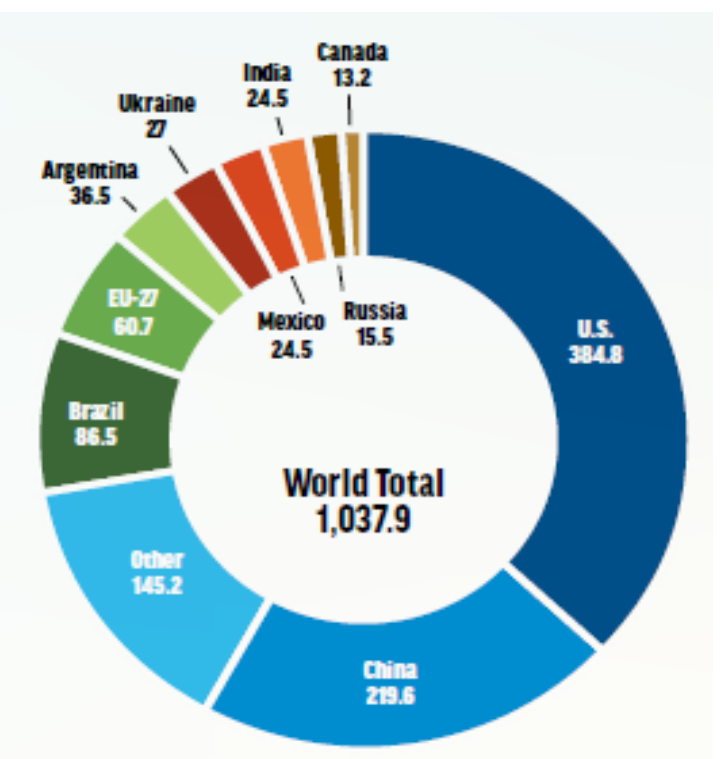

Figure 2: Outlook of the world corn production 2016 - 2017 in a million metric tonnes (FAOSTAT, 2012).

\section{E. Coconut shell ash (CSA)}

Coconut is widely grown in more than 90 countries with a global production capacity of $61.44 \mathrm{mmt}$. Shell or husk derived from coconut has been a source of environmental pollution. Apart from being used as fuel, coconut shell had no beneficial use until its ash was found to contain adequate silica and alumina for pozzolanic reaction (Table 1). Subsequently, coconut shell ash (CSA) is being explored as blended cement in concrete production. Studies carried out by Utsev and Taku, 2012 and Arum et al., 2013 showed that CSA contributes to later strength development in concrete and it is also used as aggregate in concrete (Nagarajan et al., 2014) as well as replacement for lime for soil stabilization.

\section{THE PROSPECT OF BIO-WASTES FOR ALKALI ACTIVATION}

History has it that modern alkali-activation (AA) was dated back to early 1950, when Gluchovskij et al. (1959) reported that materials rich in reactive alumina and silica have potential to form solid hydrate compound in the presence of some alkaline compounds. They developed a model through which the alkali-activation of the potential materials went through. They also identified the first stage of this reaction to be destruction-coagulation followed by coagulation-condensation and ends up with condensationcrystallization. Almost about 20 years after, precisely between 1976 and 1979, Davidovits (1994) formed a new 
Table 2: Hydraulic activity Coefficients of Selected Bio-Waste Ashes.

\begin{tabular}{lcccc}
\hline Materials/ & \multicolumn{4}{c}{ Coefficients } \\
\cline { 2 - 5 } Limit & $\mathrm{K}_{\mathrm{b}}$ & $\mathrm{CaO} / \mathrm{SiO}$ & $\mathrm{Al}_{2} \mathrm{O}_{3} / \mathrm{SiO}$ & $\mathrm{HM}$ \\
RHA & $0.03-0.09$ & $0.01-0.04$ & $0.00-0.03$ & $0.01-0.11$ \\
CPA & $0.37-1.05$ & $0.11-0.31$ & $0.13-0.26$ & $0.38-0.66$ \\
SCSA & $0.15-0.31$ & $0.04-0.17$ & $0.01-0.21$ & $0.12-0.29$ \\
CCA & $0.26-1.13$ & $0.05-0.17$ & $0.03-0.20$ & $0.17-0.32$ \\
CSA & $0.27-0.52$ & $0.01-0.14$ & $0.16-0.64$ & $0.28-0.82$ \\
Suggested Limits (Chao et. al., 2010; & $\geq 1$ & $0.5-2.0$ & $0.1-0.6$ & $>1.4$ \\
Chang, 2003; Talling and Brandstetr, & & & & \\
1989) & & & & \\
\hline
\end{tabular}

term called "geopolymer" to represent a special class of alkali activation. He defined geopolymer "as a material originated by inorganic polycondensation, i.e., by so-called "geopolymerization".

Today, both the terms "alkali activation" and "geopolymerization" are interchangeably used, though there is slight difference. In geopolymerization, the $\mathrm{Si}-\mathrm{O}-\mathrm{Si}$ bond in alumino-silicate materials break down in an alkaline medium, while an atom of $\mathrm{Al}$ penetrates the original bond to form a compound that can be characterized by $\mathrm{Mn}[-(\mathrm{Si}-\mathrm{O}) \mathrm{z}-$ Al-O]n. $\mathrm{wH}_{2} \mathrm{O}$ (Škvára, 2007). According to Davidovits (1994), replacing Si by Al generates different types of aluminosilicate (polysialate) products depending on the $\mathrm{SiO}_{2} / \mathrm{Al}_{2} \mathrm{O}_{3}$ ratio. Martinez-Ramirez and Palomo (2001) defined alkali activation as a chemical process, on the other hand, where the amorphous structure is transformed into a skeletal structure that exhibits cementitious properties through a medium of high alkalinity. In either case, the bottom line is the reaction between aluminosilicate materials and alkali activator to form a compound that has potential to bind as Portland cement does. Nevertheless, the performance of alkali-activated binder is a function of several factors, which are broadly based on the materials used and handling.

Materials used for alkali activation are categorized into two: the source material (also called solid precursor) and the alkali activator. For the source material, any material rich in reactive alumina and silica are potential candidates for alkali activation. To date, fly ash (FA) and ground granulated blast slag (GGBS) have been greatly explored for alkali activation binder, using different alkali activators. At the same time, FA and GGBS are used as pozzolan in cement-based products. These two materials are readily available in industrialized nations but not so much in developing countries. But agricultural wastes that possess comparable chemical composition with FA and GGBS are available in abundance. Thus, there is need to explore these agricultural wastes for alkali-activation

Extensive studies on mechanical and durability properties of alkali-activated concrete made from these two materials have been reported (Shi et al., 2006; Aydın and Baradan, 2013). It is worthy of note that alkali activation binder using either FA or GGBS is steadily gaining more support for deployment in life projects in most countries in Europe, China and more recently in South Africa (Glasby et al, 2015 ; Andrews-Phaedonos, 2015; Attwell, 2014).
Despite these advances in the study of alkali activated binder and its deployment, most African countries are nowhere to be found, as the research is still far from being incubated. Non-availability of FA or GGBS could be a hindrance in this respect, as most countries in the continent are non-industrialized. Similarly, most potential alkali activators are imported, which may make the alkali activated binder more expensive. However, most African countries are agrarians and produce large quantity of agricultural wastes that could be explored for alkali activation.

Moreso, if the materials are found suitable they would be available at no cost, since they are wastes while the cost of alkali could then be affordable. However, these bio-based wastes are used in blended cement as partial replacement for cement, but there is a limit to which they can be used for higher performance. For instance, the maximum tolerable amount of RHA that could be used is $40 \%$, while about $15 \%$ is recommended for other ashes, because if more ashes are used for replacement, the strength and flow properties of the blended concrete will be negatively affected. With this limitation, the materials would still not be fully utilized. Thus, considering them for alkali activation may be the best option. Besides technical improvements, environmental advantages are obtained with the use of industrial and agricultural residues in the composition of cement-based materials, such as reducing the use of raw materials in cement production and the reduction of $\mathrm{CO}_{2}$ attributed with the production of clinker.

Table 2 contains the hydraulic activity coefficients of the ash whose chemical compositions are presented in Table 1 . Basicity coefficients and hydration modulus were determined from Eqns (1) and (2) respectively (Law et al, 2012). Hydraulic coefficients are sorting parameters to assess which material could be accepted or rejected for alkali activation. In Table 1, it is seen that RHA contained mainly silica with very low content of Alumina, $\mathrm{CaO}$ and $\mathrm{MgO}$. This composition is reflected by its basicity coefficient $\left(\mathrm{K}_{\mathrm{b}}\right)$, which is less than 1 , indicating that the total content of basic constituents is less than the total content of acidic constituents, while $\mathrm{CaO}-\mathrm{SiO}_{2}$ and $\mathrm{Al}_{2} \mathrm{O}_{3}-\mathrm{SiO}_{2}$ ratios are less than the minimum allowed for materials to be acceptable for alkali activation (Chao et. al., 2010). Nevertheless, for RHA to be used for alkali activation, it may require additional material that is rich in alumina and/or $\mathrm{CaO}$ to compensate for the low content of alumina.

$K_{b}=\frac{\mathrm{CaO}+\mathrm{MgO}+\mathrm{Fe}_{2} \mathrm{O}_{3}+\mathrm{K}_{2} \mathrm{O}+\mathrm{Na}_{2} \mathrm{O}}{\mathrm{SiO}_{2}+\mathrm{Al}_{2} \mathrm{O}_{3}}$ 
$\mathrm{HM}=\frac{\mathrm{CaO}+\mathrm{MgO}+\mathrm{Al}_{2} \mathrm{O}_{3}}{\mathrm{SiO}_{2}}$

RHA could also be used as source of silica to produce low-cost silicate to be blended with alkali activator. The other bio-waste materials (CPA, SCSA, CCA and CSA) contained relatively higher $\mathrm{CaO}, \mathrm{Fe}_{2} \mathrm{O}_{3}$, and $\mathrm{Al}_{2} \mathrm{O}_{3}$ in addition to the high content of $\mathrm{SiO}_{2}$. These materials could be described as a blend of phases comparable to gehlenite $\left(2 \mathrm{CaO} \cdot \mathrm{Al}_{2} \mathrm{O}_{3} \cdot \mathrm{SiO}_{2}\right)$ and akermanite $\left(2 \mathrm{CaO} \cdot \mathrm{MgO} \cdot 2 \mathrm{SiO}_{2}\right)$ as well as a depolymerized calcium aluminosilicate glass. The cations $\mathrm{Si}^{2+}, \mathrm{Al}^{3+}, \mathrm{Mg}^{2+}$ and $\mathrm{Ca}^{2+}$ could serve as modifiers in the presence of alkali activator, although the glass phases i.e. the crystalline content may not be adequate to confirm the reactivity of these materials. There is, however, no certainty that high glass content of slag ensures higher reactivity, yet it is use as precursor for alkali activation ( $\mathrm{Li}$ et al, 2010).

From Table 2, it is also observed that the $\mathrm{Al}_{2} \mathrm{O}_{3}-\mathrm{SiO}_{2}$ ratios of these materials fell within the acceptable values. However, their basicity coefficients indicated that there are more acid contents than basic contents. Similarly, $\mathrm{CaO} / \mathrm{SiO}_{2}$ ratio for all the materials is less than the minimum acceptable value of 0.5. Meanwhile, the hydration modulus (HM) of all the ashes fell below the proposed value of 1.4. These observations suggest that the ashes from these bio wastes may require to be blended with alumina or calcium rich materials. Nevertheless, the chemical composition assessment may not be enough to generalize the performance of these materials for alkali activation. There is need for experimental investigations to assess the mechanical properties of the product formed from alkali activation of these ashes.

\section{CONCLUSION}

Bio-based materials are available in abundance and their effective disposal has been a challenge. When converted to ash, they contained oxides that make them perform excellently as partial replacement for Portland cement in cement-based products. They have not been fully utilized for alkali-activated binder. However, the ash of these agricultural wastes reviewed contained adequate quantity of silica for alkali-activation but needed to be blended with materials rich in alumina and calcium such as GGBS. Alternatively, they could be a source of silica for producing low-cost silicate mixed with $\mathrm{NaOH}$ as activator.

\section{REFERENCES}

Aderemi, P. O.; H. Mohammed, and K. A. Olonade. (2018). Effect of cassava peel ash a partial replacement of for granite dust in asphaltic concrete, Nigerian Journal of Engineering, 24(2): $16-22$.

Adesanya, O.A. ; K.A. Oluyemi, S.J. Josiah, R. A. Adesanya, L. A. J. Shittu, D. A. Ofusori, M. A. Bankole and G. B. Babalola. (2008). Ethanol Production by Saccharomyces cereviasiae from Cassava Peel Hydrolysate. The Internet Journal of Microbiology. 5(1):25-35

Adesina, A. (2012). Investigating Nigeria's agricultural value chains. A lecture presented at the Bank of Industry's
Nigerian Investment Forum, London, Federal Ministry of Agriculture and Rural Development, $1-48$.

Andrews-Phaedonos, F. (2014). Specification and Use of Geopolymer Concrete, In: $9^{\text {th }}$ Austroads Bridge Conference, Sydney, Australia.

Arum C.; C. M. Ikumapayi and G. O. Aralepo. (2013). Ashes of Biogenic Wastes-Pozzolanicity, Prospects for Use, and Effects on Some Engineering Properties of Concrete, Materials Sciences and Applications, 4, 521-527.

ASTM C 618 (2008). ASTM International, West Conshohocken, PA, www.astm.org.

Attwell, C. (2014). Geopolymer concrete: a practical approach, Proceedings of the First International Conference on Construction Materials and Structures, Johannesburg, South Africa. 466-474.

Aydın, S. and Baradan B. (2013). The effect of fiber properties on high performance alkali activated slag/silica fume mortars, Compos. B Eng. 45(1):63-69.

Bala A. I.; H. O. Aminulai, M. Abubakar, H. S. Abdulrahman and U. Musa. (2016). Partial replacement of cement with corn cob ash in concrete production, Proceedings: School of Engineering, International Conference, Minna, Nigeria, 504 - 509.

Olonade, K. A. and Bello, T. (2018). Alkali Activation of Coconut Shell Ash as Binder in Mortar. Proceedings NBBRI International Conference, Abuja, Nigeria, 23 - 31.

Boden, T.; G. Marland and R. J. Andreas. (2016). Global, regional, and national fossil-fuel $\mathrm{CO} 2$ emissions, oak ridge national laboratory, U.S. Department of Energy, Oak Ridge, Tenn., USA, available at: http://cdiac.ornl.gov/trends/emis/overview_ 2014.html, last access: 28 June 2017.

Bronzeoak Ltd. (2013). Rice Husk Ash Market Study, Exp. 129, Crown Publisher, UK.

Bui, D. D.; J. Hu and P. Stroeven. (2005). Particle size effect on the strength of rice husk ash blended gap-graded Portland cement concrete, Cement and Concrete Composites. 27(3): 357-366.

Calligaris, G. A.; M. K. Franco, K. D. Laurence, P. Aldrige, M. S. Rodrigues, A. L. Beraldo, F. Yokaichiya, X. Turrillas, and L. P. Cardoso. (2015). Assessing the pozzolanic activity of cements with added sugar cane straw ash by synchrotron X-ray diffraction and Rietveld analysis, Construction and Building Materials, 98: 44-50.

Calpe, C. (2007). Review of the rice market situation in 2007. Food and Agriculture Organization of the United Nations (FAO), Available: http://www.fao.org/docrep/fao/010/a1410t/ a1410t01.pdf.

Carstensen, K. and Rapf, O. (2008). A blueprint for a climate friendly cement industry, WWF: Nürnberg, Germany.

Chang, J. J. (2003). A study on the setting characteristics of sodium silicate-activated slag pastes. Cement and Concrete Research 33(7):1005-1011

Chao L.; S. Henghu and L. Li. (2010). A review: The comparison between alkali activated slag ( $\mathrm{Si}+\mathrm{Ca})$ and metakaolin $(\mathrm{Si}+\mathrm{Al})$ cements, Cement and Concrete Research 40:1341-1349

CEMBUREAU (2016). Cement and concrete: key facts and figures, T.E.C. Association. 
Cordeiro, G. C.; A. P. Vieira and É. Lopes. (2017). Study on the pozzolanic activity of sugar cane straw ash produced using different pretreatments quim. Nova, 40(3): 264-269.

Davidovits, J. (1994). Geopolymer In: Metha PK (ed) Proceedings of V. Mohan Malhotra symposium: concrete technology, past, present and future. ACI SP-144, 383-397

Edwards, P. (2016). The Rise and Potential Peak of Cement Demand in the Urbanized World. CORNERSTONE, Available from: http://cornerstonemag.net/the-rise-andpotential-peak-of-cement-demand-in-the-urbanized-world/

El-Sayed, M. A. and El-Samni, T. M. (2006). Physical and chemical properties of rice straw ash and its effect on the cement paste produced from different cement types, J. King Saud Univ. Eng. Sci. 19 (1):21-30.

FAO (Food and Agriculture Organization), (2016). Available: http://www.factfish. com/statisticcassava,\%20 production \%20quantity. Retrieved: 20th January, 2017.

FAOSTAT (2012). Available: http://faostat.fao.org/site/567/DesktopDefault.aspx?PageID $=567 \#$ ancor.

Glasby, T. J. R.; J. G. Day and E. F. C. Aldred. (2015). Geopolymer concrete aircraft pavements at Brisbane West Well camp Airport, Concrete 2015: 27th Biennial National Conference of the Concrete Institute of Australia in Conjunction With the 69th RILEM Week, Melbourne, Australia, 1051-1059.

Gluchovskij, V.D. (1959). Gruntosilikaty Gosstrojizdat Kiev 1959, Patent USSR 245627 (1967), Patent USSR 449894 (Patent appl. 1958, filled 1974!).

Kamau, J.; A. Ahmed, P. Hirst and J. Kangwa. (2016). Viability of using corncob ash as a pozzolan in concrete, International Journal of Science, Environment and Technology, 5(6):4532 - 4544 .

Law D. W.; A. A. Adam, T. K. Molyneaux and I.

Patnaikuni. (2012). Durability assessment of alkali activated slag (AAS) concrete, Materials and Structures (2012)

45:1425-1437

Li, C and Li, H. S. A. (2010). Review: The comparison between alkali activated slag $(\mathrm{Si}+\mathrm{Ca})$ and metakaolin $(\mathrm{Si}+\mathrm{Al})$ cements Cement and Concrete Research 40, 1341-1349

Mahungu, N. and Anga, B. (2007). NEPAD Pan African Cassava Initiative (NPACI). Available: https://docslide.net/documents/nepad-pan-african-cassavainitiative-npaci-n-mahungu-and-b-anga-the-first.html.

Martinez-Ramirez, S., and Palomo, A. (2001). Alkaliactivated fly ashes-A cement for the future. Cement and Concrete Research, 31(11):1581 1585.

Moise's F. E.; E. Villar-Cocina and E. ValenciaMorales. (2007). Characterisation of sugar cane straw waste as pozzolanic material for construction: calcining temperature and kinetic, Waste Management, 27(4):533-538.

Nagarajan, V. K., S., Aruna, S. P. Devi, M. Manohari and M. Santha. (2014). Experimental study on partial replacement of cement with coconut shell ash in concrete, International Journal of Science and Research (IJSR), 3(3): $23-30$.
Nimityongskul, P. and Daladar, T. U. (1995). Use of coconut husk ash, corn cob ash and peanut shell ash as cement replacement, Journal of Ferrocement, 25(I): 35-44.

Olonade, K. A.; M. B. Jaji, and O. A. Adekitan. (2017). Experimental comparison of selected pozzolanic materials, African Journal of Science, Technology, Innovation and Development, DOI: 10.1080/20421338.2017.1327931

Olonade, K. A.; A. M. Olajumoke, A. O. Omotosho and F. A. Oyekunle, (2014). Effects of sulphuric acid on the compressive strength of blended cement/cassava peel ash concrete, Construction Materials and Structures, S.O. Ekolu et al. (Eds.), IOS Press, 764 - 771, 2014. doi:10.3233/978-161499-466-4-764.

Olonade, K. A. (2017). Benefit - cost analysis of recycling solid wastes in concrete: a case study of cassava peels in Nigeria, Research Journal of Engineering and Environmental Sciences 2(1): $1-8$.

Olutaiwo A.O. and A. Adanikin. (2016). Evaluation of the structural performance of lateritic soil stabilized with cassava peel ash (CPA) and cement, International Journal of Constructive Research in Civil Engineering (IJCRCE), 2(2):18-26.

Pitt N. (1972). Process for the preparation of siliceous ashes, US Patent, 3959007, July 1972.

Raheem, A. A. and Adesanya D. A. (2011). A study of thermal conductivity of corn cob ash blended cement mortar The Pacific Journal of Science and Technology, 12(2):106 111.

Ramezanianpour, A. A.; M. Mahdikhani, and G. Ahmdibeni. (2009). The effect of rice husk ash on mechanical properties and durability of sustainable concretes, International Journal of Civil Engineering. 7(2):83 - 91

Reddy, T. S. and Prasad D. S. V. (2017). Stabilization of soil using sugarcane straw ash and polypropylene fibres, International Journal of Engineering and Applied Sciences (IJEAS), 4(6):5 -8.

Salau, M. A. and Olonade, K. A. (2011). Pozzolanic potentials of cassava peel ash, Journal of Engineering Research, 16(1):10-21.

Salau, M. A.; E. E. Ikponmwosa and K. A. Olonade. (2013). Effect of elevated temperature exposure on cassava peel ash concrete, American Journal of Materials Science, 3(5): $142-148$.

Santos, V.; M. S. Rodrigues, L. Rodier, G. C. Brito and H. Savastano, (2015). kinetic reactions on cementitious matrices with sugarcane industry ashes https://umanitoba.ca/faculties/engineering/departments/ce2p2 e/alternative

village/media/16th_NOCMAT_2015_submission_127.pdf

Scrivener K. L.; V. M. John, and E. M. Gartner (2016). Eco-efficient cements: Potential economically viable solutions for a low-CO2 cement-based materials industry, UNEP Report (2016)

Shi, C.; D. Roy and P. Krivenko (2006). AlkaliActivated Cements and Concretes, CRC Press, UK.

Škvára, F. (2007). Microstructure of Cement-based systems/Bonding and Interfaces in Cementitious Materials 
Available:

http://www.geopolymery.eu/ aitom/upload/documents/publikace/2007/2007_praha_skvara. pdf. $661-667$.

Talling B and Brandstetr J. (1989). Present state and future of alkali-activated slag concretes. In: Proceedings third international conference on fly ash, silica fume, slag, and natural pozzolans in concrete. Trondheim, Norway.

Tashima M. M.; A. R. Carlos Da Silva, J. L. Akasaki and M. B. Barbosa. (2016). The Possibility of Adding the Rice Husk Ash (RHA) to the Concrete Available: http://citeseerx.ist.psu.edu/viewdoc/download?doi=10.1.1.48 $2.8775 \&$ rep $=$ rep $1 \&$ type $=$ pdf

Taylor, R. D. (2016). 2016 Outlook of the U.S. and World Sugar Markets, 2016-2025, Agribusiness and Applied Economics Report 751, Center for Agricultural Policy and Trade Studies. 1-26.
Tinga T. L.; R. P. Jayaa, N. AbdulHassana, H. Yaacoba, D. S. Jayantib and M. MohdAriffinc (2016). A review of chemical and physical properties of coconut shell in asphalt mixture, Jurnal Teknologi, 78(4):85 -89

Utsev, J. T. and Taku, J. K. (2012). Coconut shell ash as partial replacement of ordinary Portland cement in concrete production, International Journal of Scientific \& Technology Research. 1(8):12 - 21

Zhang, M. H, and Mohan, M.V. (1996). Highperformance concrete incorporating rice husk ash as a supplementary cementing material, ACI Materials Journal. 93(6): 629- 636. 